\title{
O PRINCÍPIO DE IGUALDADE ENTRE CÔNJUGES
}

\author{
Maria Regina Pagetti Moran
}

Mestra em Direito Civil pela Faculdade de Direito da Universidade de São Paulo, Auxiliar de Ensino da Faculdade de Direito da Universidade Católica de Santos.

Resumo: O conceito de igualdade por provocar posições extremadas é o tema deste estudo. Enfoca-se em primeiro plano aspectos constitucionais do princípio de isonomia, bem como aspectos sociológicos da desigualdade da mulher, à guisa de fundamentar o tratamento desigual e o papel secundário atribuído à mulher pela legislação brasileira. Objetivou-se demonstrar a necessidade de releitura do Direito de Família inscrito no Código Civil de 1916, harmonizando-o com os dispositivos da Constituição Federal de 1988, principalmente quando esta consagra em seu corpo, não apenas uma igualdade formal, mas um princípio de isonomia verdadeiramente material - há igualdade de direitos e obrigações, sem quaisquer distinçōes de sexo, raça, cor ou credo e não apenas "igualdade perante a lei".

\begin{abstract}
The extreme positions produced by the concept of equity made us consider it as theme of this study. We focalize, first sight, constitutionals, and sociologicals aspects of the equity principle and womens'unequality, just to explain the inferior and secundary paper Brasilian's legislation gives to the married woman. The objective was to show the real necessity of to read again the Family Law we have written in the Civil Code of 1916, and to harmonize it with the new Constitutionals dispositives (Brasilians'Federal Constitution, of 1988). The subject gains a new and great importance today because the Federal Constitution ordains, not more a formal equity: "everybody is equal before the law"; but a material equity: "there is equity in rights and obligations, without no distinctions of sex, race, color or religion.
\end{abstract}

Unitermos: Igualdade entre Cônjuges; Isonomia; Igualdade de Direitos e Obrigaçōes.

\section{SUMÁRIO}

I - Situação do tema

I - O princípio de igualdade entre cônjuges no Direito brasileiro

A. Código Civil de 1916

a.1 Chefia da sociedade conjugal

a.2 Representação legal da família

a.3 Administração dos bens comuns 
a.4 Domicilio conjugal

a.5 Manutenção da familia

a.6 Direção material e moral da família

a.7 O nome da mulher casada

B. Projeto de lei $\mathrm{n}^{2}$ 634-B de 1975 , o novo estatuto civil da mulher e o projeto de lei $\mathrm{n}^{\mathrm{Q}} 2.022 / 1989$.

III - O conflito: a nova ordem constitucional e o código civil

A. Supremacia da Constituição

B. Aplicabilidade do princípio de isonomia

IV - Propostas

V - Bibliografia

\section{O princípio de igualdade entre cônjuges}

\section{I - Situação do tema}

"Todo ser humano é pessoa, sujeito de direitos e deveres. Em uma convivência humana bem constituída e eficiente, é fundamental o princípio, de que cada ser humano é pessoa; isto é, natureza dotada de inteligência e vontade livre. Por essa razäo, possui em si mesmo direitos e deveres universais, invioláveis e inalienáveis!" (João XXIII, Pacem In Terris, n² 9)

O conceito de igualdade provoca posições extremadas. Os nominalistas sustentam ser a desigualdade característica do universo. Os seres humanos nascem e perduram desiguais; a igualdade não passa de um simples nome, sem significado no mundo real. Os idealistas postulam igualitarismo absoluto entre as pessoas - estão no polo oposto. Os realistas, em posição intermediária, reconhecem que os homens são desiguais em vários aspectos, mas são iguais porque, em cada um deles, o mesmo sistema de características inteligíveis proporciona, à realidade individual, aptidão para existir. Em essência os homens são iguais (SIIVA, J. Afonso da. Curso de Direito Constitucional Positivo, São Paulo, RT, $5^{\mathrm{a}}$ ed., 1989, p. 188).

A lei deve ser instrumento regulador da vida social e não fonte de privilégios ou perseguições. O princípio da isonomia absorve tal conteúdo político-ideológico e juridicisa-o nos textos constitucionais irradiando-o para os sistemas normativos vigentes.

Igualdade significa qualidade de igual, uniformidade; eqüidade, retidão, paridade; em matemática, expressão, da forma $\dot{A}=\mathrm{B}$, que indica serem duas quantidades (numéricas ou literais) iguais. Igual significa idêntico, liso, que tem a mesma grandeza ou mesmo valor; que tem a mesma condição ou categoria; uniforme, inalterável. (FERREIRA, A. B. de Hollanda. Pequeno Dicionário. Ed. 1972, p. 652) 
Não há, entre os homens, igualdade aritmética, pois uns são altos, outros baixos; uns negros, outros brancos; artistas, cientistas, trabalhadores manuais, etc., mas a igualdade geométrica prevalece entre eles. Nesse sentido diz Pontes de Miranda: "Também at a divisão do trabalho, o aperfeiçoamento das aptidões, a própria utilização das compensaçōes psíquicas $e$ outras diferenças individuais servem a cada vez maior prevalência da igualdade geométrica. Porque os homens não são aritméticas iguais e, além disso, a igualdade é coisa a realizar-se, e não realizada, o conceito de 'igualdade' é sempre relativo" (Pontes de Miranda. Comentarios a Constituição de 1967. T. IV, p. 666).

A problemática da igualdade entre os sexos insere-se dentro de uma preocupação maior, a da igualdade entre os seres humanos. As constituições modernas, ora limitam-se a uma proclamação de igualdade do homem e da mulher perante a lei, equivalente a uma proibição de discriminações legislativas, ora à consagração de uma igualdade absoluta de direitos entre homens e mulheres.

A Constituição brasileira de 1988 filia-se ao segundo modelo. Apontam-se duas razões fundamentais: as relações entre homens e mulheres se dão em todos os campos da atividade social, indo desde as relações no trabalho, na política, nas religiões e organizações, em geral, até chegar ao recanto do próprio lar, onde homem e mulher se relacionam fundamentalmente sob a instituição do casamento.

Celso Ribeiro Bastos reconhece que esta disposição constitucional só se aperfeiçoará e se tornará eficaz na medida em que a própria cultura se altere (Cf. Comentários à Constituição do Brasil. São Paulo, Saraiva, 1989, 2 v. p.18). A regra do artigo 52, inciso I da Constituição Federal de 1988 resume décadas de lutas das mulheres contra discriminaçốes. Não se trata aí de mera isonomia formal. Não é igualdade perante a lei, mas igualdade em direitos e obrigações. Não é mais admissível que sob a alegação de desigualdade biológica, fisiológica, psicológica e outras, encubra-se uma verdadeira diferenciação de dignidade jurídica, moral e social entre ambos os sexos.

A conquista da paridade é lenta e trabalhosa, depende de verdadeira Revolução Social. A mulher, tal como a história demonstra, tem sido marginalizada e discriminada ao longo dos séculos. Teorias se formaram na tentativa de justificar a inferioridade da mulher no contexto social. Inferioridade esta aplicada à luz da propria natureza, da biologia, da fisiologia, da psicologia, e outras ciências. Pode-se afirmar, porém, que a inferioridade feminina e a decantada superioridade masculina constituem apenas dado sócio-cultural, interferindo em nada, ou quase nada, a natureza.

A sociedade de classes é apontada por sucessivos autores como responsável pelo estado de divisão entre homem e mulher.

Estruturalmente, diz Leonardo Boff, a nossa sociedade, em moldes capitalistas e altamente competitiva, recalca a mulher. "Em outras sociedades, nas quais se reduz a competitividade e se favorece a cooperaçäo, existem as condiçōes de gratificar mais a mulher. Num meio igualitário, os papéis sexuais são igualmente muito mais igualitários e fraternos. Uma divisão social do trabalho menos binária produz também menores diferenças entre os sexos: os varões possuem 
comportamentos mais femininos e as mulheres mais masculinos. Dados transculturais vêm confirmar este tipo de hipótese baseada na interaçāo entre o biologico e o cultural" (Cf. O Rosto Materno de Deus. Petrópolis, Vozes, 1979, p.52/53).

Evelyn Reed, expoente da ala revolucionária do movimento feminista americano, confirma a visão acima exposta, embora com ênfase especial à luta de classes: "Não foi a natureza, e sim a sociedade de classes que rebaixou a mulher $e$ elevou o homem. Os homens obtiveram sua supremacia social através da luta contra a mulher e suas conquistas. Mas esta luta contra os sexos era somente uma parte da grande luta social: o desaparecimento da' sociedade primitiva e a instituiçāo da sociedade de classes. $A$ inferioridade da mulher é produto de um sistema social que causou e proporcionou inumeráveis desigualdades, inferioridades, discriminaçōes $e$ degradaçōes. Mas esta realidade histórica foi dissimulada atrás de um mito da inferioridade feminina". (Ver Sexo Contra Sexo ou Classe Contra Classe. Ed. Proposta Editorial/Versus, $1^{2}$ ed., 1980, p.34).

Quando um indivíduo ou um grupo é mantido em situação de inferioridade, torna-se inferior; $e$, se as mulheres ainda hoje são inferiores na concepção cultural dos homens, a elas são oferecidas, por um mesmo modelo cultural, menores possibilidades de se livrar dele (Cf. VERUCCI, Florista. A Mulher e o Direito. São Paulo, Nobel, 1987, p.13).

Frei Leonardo Boff (A Ave-Maria, O Feminismo e o Espirito Santo. Petrópolis, Vozes, 1980, p.11/12), afirma que sem a integração consciente do feminismo ficamos todos mais pobres:

"A libertaçāo não significa um processo de vindita histórica ou de concorrência dos sexos. Significa a açäo que liberta a liberdade de uns e de outros, superando os mecanismos de dominação e propiciando os caminhos que vão do coraçāo da mulher ao do varão e do coração do varäo ao da mulher."

II - O princípio da igualdade entre cônjuges no direito brasileiro

\section{A. Código Civil de 1916}

O Código Civil Brasileiro de 1916 assume posição avançada em relação ao direito anterior, mas, inegavelmente, traz em si, bem nítidas, as marcas da predominância masculina.

O autor do Projeto do Código Civil Brasileiro, ao conservar o poder marital, justifica sua concepção mediante os altos propósitos de manutenção da unidade familiar.

O exercício desse poder, lembra Oliveira Deda, "conferia ao marido privilégios que, em última análise, redundavam na submissão da mulher a seu jugo" (Cf. Direito Matrimonial. In Enc. Saraiva do Direito, v.27:272-279).

Durante o Império, quando, por força da Lei de 20 de outubro de 1823, ainda vigoravam no Brasil, as Ordenações, Leis, Regimentos, Alvarás, Decretos e Resoluções promulgadas pelos reis de Portugal até 25 de abril de 1821, a mulher brasileira vivia em situação de insustentável opressão. 
O lado triste e quiçá pitoresco da história das instituições jurídicas no Brasil é o fato de que, enquanto aqui se conservavam as vetustas e inadequadas Ordenações do Reino, que desta forma completaram 314 anos de existência, Portugal e toda a Europa viviam uma nova era do direito a era do individualismo, do liberalismo (ver Braga da Cruz. A Formaçāo Histórica do Moderno Direito Privado Português e Brasileiro. In Revista da Faculdade de Direito da USP, 1955, $\mathrm{n}^{\circ}$ 50:67).

Maria Thereza Caiuby Crescenti Bernardes, em pesquisa inédita sobre as mulheres na sociedade carioca do século XIX, comenta vários artigos publicados, na Cidade do Rio de Janeiro, pelo Jornal das Senhoras, verdadeiros protestos contra a situação de desigualdade da mulher na sociedade brasileira do século XIX (Cf. Mulheres de Ontem? Rio de Janeiro - Século XIX. São Paulo, T.A. Queiroz Editor, 1989 , p. 144).

Registre-se que em matéria civil, a época referida, vigorava no Brasil a Consolidação das Leis Civis, elaborada por Teixeira de Freitas, em 1858.

Clovis Bevilaqua procura justificar os dispositivos do Código Civil de 1916 referentes à situação da mulher na família argumentando em linhas gerais o seguinte:

1) O marido encontrava-se (à epóca), perante o maior número de legislaçooes vigentes, investido de uma certa autoridade ou tutela sobre a sua consorte;

2) Apesar do artigo 6, II do Código Civil Brasileiro, afirma o citado autor, não se podia afirmar que a mulher casada sofresse incapacidade civil;

3) O passado exerceu poderosa ação para a permanência da situação de inferioridade da mulher;

4) Reconhece que o futuro trará modificações ao regime que intitula de "caturrice", embora afirme: "sem aliás pensar numa emancipação incompativel com $o$ recato $e$ os melindres próprios do sexo feminino" (Cf. Direito de Familia, Edição Historica, Ed. Rio, 1976, p.154, § 28.

O Código Civil Brasileiro transformou o poder pessoal do marido em autoridade, bem mais próxima à idéia de função mas, introduziu a regra do artigo 6., a qual, em franca humilhação para a mulher casada, colocava-a ao lado dos incapazes, isto $\epsilon$, dos silvícolas, pródigos e menores entre 18 e 21 anos; tirando da mãe que contraísse novas núpcias o pátrio poder sobre os filhos do primeiro leito tal pátrio poder passava para as mãos do novo marido.

A bem da verdade, Clóvis Beviláqua julgava desnecessária a consagração da incapacidade relativa da mulher casada. São palavras do autor do Projeto (Código Civil Comentado, $10^{\mathrm{a}}$ ed., v.I, p.153): "Realmente, a mulher possui capacidade mental equivalente à do homem, e merece igual proteção do direito. Já é um sacrificio d justiça submetê-la da autoridade do marido, pela necessidade de harmonizar as relaçōes da vida conjugal".

À época da aprovação do Código Civil Brasileiro algumas vozes se levantaram insurgindo-se contra a adoção do princípio da autoridade marital. $O$ fato pode ser confirmado através do exame dos "Trabalhos da Câmara", volume IV, p. 
113: " $A$ concepçāo da sociedade, no momento presente, nāo exige mais, como outrora, que a família se apoie sobre a base egoistica da autoridade, parece mais sólida, mas resistente e eficaz a base altruística do amor e do respeito mútuo".

Outro erro grave do legislador da época, ao elencar a mulher casada entre os relativamete incapazes, foi confundir o conceito de incapacidade com o de falta de legitimação.

$O$ problema não é de incapacidade, mas de falta de legitimação. A incapacidade envolve uma inaptidão interna, um defeito de ordem física ou psíquica que impede o menor pela sua imaturidade, o amental pela escassez de siso, ou o silvícola pela falta de tirocínio, de julgarem de maneira adequada. Enquanto que a falta de legitimação ocorre quando a lei, tendo em vista a posição peculiar de determinadas pessoas em face de um negócio, lhes proíbe de atuar em uma dada relação jurídica (Ver Silvio Rodrigues. Direito Civil. São Paulo, Saraiva, 18a.ed., v.I, p.54 e nota 37).

O artigo 233 do Código Civil Brasileiro considerava a mulher como atendente do marido. Assim é que Pontes de Miranda, ao tecer consideraçöes sobre a posição jurídica do marido, doutrina: "O marido é o chefe da sociedade conjugal." Compete-lhe, assim, como corolários morais de sua situação no seio da familia:

I - O direito a ser atendido pela mulher, devendo essa, no que seja justo e honesto, moldar suas ações pela vontade dele... A civilização moderna completou a obra do Cristianismo e igualou, em sua situação recíproca, a mulher e o marido. Já nos repugnam os textos das Ordenações Filipinas, Livro V, Título 36, § 1., e Título 95, § 4., que davam ao homem o direito de castigar a sua companheira" (Cf. Pontes de Miranda, Tratado de Direito Privado, Tomo VIII, p. 116).

Diante da reforma promovida pela Lei n. 4.121, de 27 de agosto de 1962, bem como do princípio de isonomia material determinado pela Constituição Federal de 1988, ninguém mais pode, em sã consciência, atribuir à mulher casada a função de "atendente do marido".

\section{a.1. Chefia da Sociedade Conjugal}

Art. 226 - A familia, base da sociedade, tem especial proteção do Estado.

$\$ 5^{\circ}$ - Os direitos e deveres referentes à sociedade conjugal são exercidos igualmente pelo homem e pela mulher (Constituição Federal do Brasil).

A chefia da sociedade conjugal era corolário do antigo poder marital, expressão hoje em desuso. No poder marital estavam enfeixados uma gama de direitos particulares conferidos ao marido em razão de sua superioridade, decorrente dos "predicados do seu sexo", segundo concepção de Lafayette, o tornavam mais apto a exercê-lo (Orlando Gomes, Direito de Família, Rio de Janeiro, Forense, 7.ed., 1990, p. 131).

O marido, como conseqüência do poder marital, era titular dos seguintes direitos: a) o de exigir obediência da mulher, a qual era obrigada a moldar suas ações pela vontade dele em tudo que fosse honesto e justo; b) o de fixar e escolher o domicilio conjugal, no qual a mulher devia acompanhá-lo; c) o de representar e 
defender a mulher nos atos judiciais e extrajudiciais; d) o de administrar os bens do casal, podendo dispor dos móveis livremente, dos imóveis com restrições da lei; e) o de corrigir a mulher, podendo castigá-la corporalmente.

O Código Civil de 1916 derrogou várias dessas prerrogativas, mas a chefia da sociedade conjugal do marido não desapareceu.

Mesmo antes do advento da Constituição Federal de 88, sob a égide das constituições brasileiras anteriores, os dispositivos do Código Civil que contém discriminações em razão do sexo já eram considerados inconstitucionais.

Hoje, conforme dispõe o artigo 226, $\$ 5^{\circ}$ da Constituição Federal "os direitos $e$ deveres referentes à sociedade conjugal são exercidos igualmente pelo homem e pela mulher".

O artigo 233 do Código Civil Brasileiro encontra-se derrogado, e, portanto, extinta a chefia da sociedade conjugal como direito do cônjuge varão.

Impõe-se uma releitura do tema - Não se deve falar mais em "chefia da sociedade conjugal", mas em direitos e deveres cujos titulares sāo ambos os cônjuges em igualdade de condições.

\section{a.2. Representação Legal da Familia;}

Compete-lhe:

I - a representação legal da família;

A familia não possui personalidade jurídica não sendo titular de direitos e obrigaçōes na esfera civil.

O artigo 233, inciso I do Código Civil Brasileiro, deu margem a memoráveis equivocos por parte dos seus intérpretes e aplicadores.

Alguns acórdãos chegaram a entender que o legislador de 1916 tivera a intenção de outorgar ao marido o direito de representar a mulher e os filhos (Cf. Silvio Rodrigues. Direito de Familia. 16ª ed., 1989, p. 137, nota 104).

$O$ preceito da representação da familia pelo marido foi introduzido no Código Civil Brasileiro por força de antiga tradição, justificado como corolário do poder marital. Assim é que a vetusta lição de Lafayette apregoava: "ao marido, em virtude do poder marital, compete o direito de representar e defender a mulher nos atos judiciais e extrajudiciais".

Mas, essa representação, advertia Beviláqua, não poderia importar na absorção da personalidade da mulher, nem tão pouco dos filhos (Cf. Comentários. v. II, p.90).

Atualmente, diante da Lei $4.121 / 62$ e do artigo 226 , $\S 5^{\varrho}$ da Constituição Federal, o inciso I do artigo 233 do Código Civil está derrogado. 


\section{a.3. Administração dos Bens Comuns}

Art.266 - Na constância da sociedade conjugal, a propriedade e posse dos bens é comum.

Parágrafo único - A mulher, porém, só os administrará por autorização do marido, ou nos casos do art.248, V, e art.251.

$\mathrm{O}$ inciso II do artigo 233 decorria da atribuição da chefia da sociedade conjugal ao marido e, entra em choque com o artigo $226, \$ 5^{\circ}$ e artigo $5^{\circ}$, I da Constituição Federal em vigor. O texto do artigo 266 do Código Civil Brasileiro encontra-se, também, derrogado por força dos dispositivos constitucionais acima mencionados.

O preceito do artigo 274 exige releitura, substituindo-se a palavra marido por ambos os cônjuges; a expressão por este contraídas por por dívidas por eles contraidas; a expressão particulares de um e outro cônjuge, por particulares de cada cônjuge. Marido e mulher (artigos $5^{\circ}, \mathrm{I}$ e $226, \S^{\circ} \mathrm{da}$ CF.), são iguais em direitos e obrigações e no exercício dos direitos da sociedade conjugal.

\section{a.4. Domicílio Conjugal}

Art.233 -

III - o direito de fixar o domicilio da familia, ressalvada a possibilidade de recorrer a mulher ao juiz, no caso de deliberação que a prejudique.

A doutrina brasileira consagrou o princípio do inciso III do artigo 233 , em sua primitiva redação, como decorrência lógica da posição do cônjuge varão na familia. À jurisprudência coube a dosagem da aplicabilidade desta prerrogativa do marido que, conjugada com o artigo 233 , II criava para a mulher uma verdadeira obrigação de acompanhar o marido, cada vez que este desejasse mudar o domicilio conjugal.

O abandono do lar estaria facilmente caracterizado se a mulher se negasse, injustificadamente, a acompanhar o marido, transcorridos dois anos, a contar da recusa. O preceito do artigo 317 do Código Civil, em vigor até que fosse revogado pela Lei do Divórcio (Lei n. 6.515, de 26/12/77), autorizava o desquite, mesmo se a recusa datasse de menos de dois anos, pois havia o entendimento corrente de que o fato configurava injuria grave.

A Lei 4.121/62 cria um novo direito para a mulher ressalvando-lhe a possibilidade de recorrer ao juiz, nos casos de deliberação do marido que a prejudique.

Roberto Salles Cunha (Os Novos Direitos da Mulher. São Paulo, Atlas, 1990, p.86) reconhece ser, "na prática, rara essa ação judicial, dada a passividade da mulher $e$ o receio da perda dos alimentos, por abandono do lar (além do seqüestro temporário de parte dos rendimentos particulares - art.234 C.C.) - medida, porém, poucas vezes decidida". 
A regra do artigo 233, III do Código Civil acabava por impedir o afastamento da mulher do lar conjugal, refletindo na proibição do exercício de profissão sem a autorização do marido. $O$, exercício de uma profissão, fora do lar conjugal, criar-lhe-ia um centro de ocupações habituais possivelmente distinto daquele do marido.

\section{a.5. Manutenção da Familia}

Art.233 -

IV - .

A Lei $\mathrm{n}^{2} 4.121 / 62$, em seu artigo $2^{9}$ passou a dispor o seguinte:

Art.29 - A mulher, tendo bens ou rendimentos próprios, será obrigada, como no regime da separação de bens (art. 277 do Código Civil) a contribuir para as despesas comuns, se os bens comuns forem insuficientes para atendê-las.

Antes da reforma constitucional de 1988 incumbia ao marido o encargo de manutenção da familia, com as exceções dos artigos 275 e 277 do Código Civil e art. $2^{\circ}$ da Lei 4.121/62.

$\mathrm{O}$ artigo 226 , § $5^{2}$ da CF, impõe situação de absoluta igualdade ficando reforçada a concepção de que a mulher deve participar, tanto quanto o marido, do sustento da familia, na proporção dos seus bens e rendimentos do seu trabalho.

\section{a.6. Direção Material e Moral da Familia}

Art.240 - A mulher, com o casamento, assume a condição de companheira, consorte e colaboradora do marido nos encargos de familia, cumprindo-lhe velar pela direção material e moral desta (Redação cf. Lei n² 6.515/77).

O artigo 240 do Código Civil Brasileiro impõe ônus à mulher em todas as suas sucessivas formas redacionais. A mulher continua arcando com a dupla e injusta jornada de trabalho. Além do trabalho profissional, fora do lar, deve velar pela direção material e moral da familia.

Enquanto a divisão equânime da carga extra de trabalho doméstico, criação e educação dos filhos, não imposta ao homem, não haverá equilíbrio, representado pela perfeita igualdade de direitos e obrigações.

Uma das propostas da OCDE (Organização para Cooperação e Desenvolvimento Econômico) para coibir a discriminação do trabalho da mulher é, justamente, a instalação de programas de divisão das responsabilidades familiares.

Apesar da evolução registrada no campo educacional e formativo da mulher, ainda há diferenças substanciais no tipo de educaçåo ministrada aos meninos e meninas. A mulher precisa receber uma educação adequada que corrija as distorções na sua formação e the possibilite desenvolver suas potencialidades máximas no seio do mercado de trabalho (Cf. Informe OCDE, 1984).

Judith Hole e Ellen Levine (Rebirth of Feminism, New York, Quadrangle Books, 1971, p. 85/86) escrevem que uma verdadeira parceria entre sexos requer um conceito diferente de casamento, onde haja a partilha eqüitativa das 
responsabilidades do lar, das crianças e dos fardos econômicos para sustentá-los. Acreditam que um conhecimento apropriado deveria ser dado aos valores econômicos sociais representados pelo trabalho doméstico e cuidado da criança.

- Manifestam-se igualmente contrárias às práticas protecionistas do Estado, da igreja, colégios, fábrica ou escritório que acabam, à guisa de proteção, por negar oportunidades e incutir nas mulheres autodenigrimento, dependência, e evasão de responsabilidade, minando a auto-confiança e fomentando desrespeito pelas mulheres.

\section{a.7. O Nome da Mulher}

Art.240

Parágrafo único - $A$ mulher poderá acrescer aos seus os apelidos do marido (parágrafo acrescentado pelo art.50 da Lei $n^{2} 6.515$ de 26/12/77).

A tendência mais avançada não é a de se considerar a mulher como companheira, consorte e colaboradora, mas sim como portadora de mútua responsabilidade. $\mathrm{O}$ uso de apelidos (na lei civil, nome é denominado apelido; na linguagem comum, apelido é alcunha) do marido era uma tradição oriunda do direito romano; tratava-se de uma obrigação. A Lei do Divórcio (6.515/77) introduziu o parágrafo ínico do artigo 240, tornando o uso dos apelidos do marido uma faculdade. A antiga obrigação de assumir, com o casamento, os apelidos do marido transformou-se em direito. A mulher "poderá" acrescê-los aos seus ou não, mantendo o seu nome de solteira. O marido não pode, sem anuência dela, modificar-lhe o nome no Registro Civil.

Comenta o Professor Rubens Limongi França que o artigo 50 da Lei do Divórcio (6.515/77) está em franca contradição com o artigo 18 do mesmo diploma. Isto porque defere à mulher o direito de usar o nome do marido, sem que se lhe imponha a obrigação respectiva. O artigo 18 da citada Lei do Divórcio dispõe: "Vencedora na ação de separação judicial (art. $5^{\circ}$ "caput"), poderá a mulher renunciar, a qualquer momento, ao direito de usar o nome do marido".

O que implica reafirmar que o nome do marido, em princípio, é direito e obrigação, pois só se defere à mulher a faculdade de renúncia, se vencedora (Cf. FRANÇA, Rubens Limongi. Comentário à Lei do Divórcio, Belém, CEJUP, 1984, p.94).

O princípio de igualdade patenteado pela Constituição exige se faça uma releitura do artigo 240 do Código Civil, facultando a ambos os cônjuges (e não só à mulher) acrescer ao seu os apelidos do marido.

O Projeto de Lei $\mathbf{n}^{\mathrm{Q}}$ 2.022/89, apresentado por Irma Passoni (DCN, 2004/1989, p.2.464), dispõe sobre o Código Civil e propõe a seguinte redação para o atual artigo 240 do C.C.:

Art.240 - Pelo casamento, homem e mulher assumem mutuamente a condiçạ̃o de consortes, companheiros e responsáveis pelos encargos de familia.

Parágrafo único - É facultado a ambos os cônjuges que um deles acresça aos seus os apelidos do consorte. 


\section{B. Projeto de Lei 634-B/75, Novo Estatuto Civil da Mulher e Projeto de Lei n 2.022/89}

O Projeto do Novo Código Civil Brasileiro (634-B/75) introduziu várias modificações e alguns avanços, mas, na verdade, não extinguiu a chefia da sociedade conjugal. Privilegia o marido em caso de divergência, prevalecendo a vontade deste, ressalvada à mulher a faculdade de recorrer ao judiciário, desde que não se trate de matéria personalíssima (art. 1.569, caput e Parágrafo Único).

O Novo Estatuto Civil da Mulher teve seu Anteprojeto elaborado por Florisa Verucci e Sívia Pimentel, com a colaboração de vários juristas. Trata-se de trabalho valioso e atualizador dos textos do Projeto do Novo Código Civil, entretanto encontra-se no Congresso Nacional.

Os pontos principais do Anteprojeto do Novo Estatuto Civil da Mulher são os seguintes:

a) revogação do instituto da chefia da sociedade conjugal, com as conseqüências necessárias sob o enfoque da lógica jurídica, ou seja:

- eqüidade na atribuição da administração dos bens do matrimônio, assumindo a mulher as mesmas atribuições do marido em relação aos bens do casal e dos filhos menores;

- liberdade ampla para a escolha do nome da familia, podendo a mulher adotar ou não o nome da família do marido, assim como este também poderia adotar o nome da família da mulher, como ocorre em algumas legislações estrangeiras.

b) - alteração da terminologia do pátrio poder, passando para autoridade parental, à semelhança do direito moderno francês e inspirada na realidade das relações entre pais, mães e filhos na sociedade de hoje, onde não cabem mais as formas de posse e poder, mas'sim as de função e de responsabilidade.

c) eliminação dos dispositivos abertamente injustos, como os já referidos arts. 178 e 219 (erro essencial de pessoa) e art. 1.744,III (filha desonesta), já proposta pelo projeto.

d) - eliminação do instituto do regime total de bens, também revogado no Projeto do Código Civil, por estar em completo desuso há muitos anos.

e) - inclusão, no artigo sobre os deveres do casamento, de mais um dever expresso: respeito e consideração mútuos, a exemplo do Código Civil Português.

Sabemos que lei alguma, por si só, é suficiente para alterar os costumes. Apesar dos movimentos de mulheres e das conquistas dos últimos dez anos a sociedade brasileira passará ainda por uma longa luta até que a realidade se transforme.

Forçoso reconhecer que a participação da mulher nos negócios do casal e da familia, dependerá de seu grau de consciência pessoal e de seu conhecimento, através da educação e dos meios de comunicação, das leis que lhes atribuem direitos e instrumentos legais para que exijam o cumprimento desses direitos (Cf. F. Verucci. A Mulher e o Direito. São Paulo, NOBEL, 1987, p.80). 


\section{III - O Conflito: A Nova Ordem Constitucional e o Código Civil}

\section{A. A supremacia da Constituição}

Constituição, no sentido substancial, é o conjunto de normas que determinam a estrutura mesma do estado, ou seja - os principais traços de sua forma ou configuração, incluindo a organização do poder estatal em suas funções legislativa, executiva e judiciária, a definição de suas competências, bem como, usualmente, os direitos humanos e suas garantias fundamentais. Em sentido formal é conjunto das regras que foram postas como Constituição, compondo o seu texto, versem ou não sobre matéria tipicamente constitucional, e que têm a força vinculativa peculiar, específica, de Constituição. Constituição em sentido material é o conjunto, não de normas, mas das forças sociais, políticas, econômicas, ideológicas, fáticas, em suma, que conformam a realidade sociopolítica de determinado Estado, configurando sua particular estrutura ou maneira de ser (Cf. Ferraz Jr., Diniz e Georgakilas, Constituição de 1988 (Legitimidade, Vigência e Eficácia, Supremacia), São Paulo, Atlas, 1989, p.94).

A Constituição Brasileira de 1988 foi "prodigamente dotada de normas consagradoras da sua supremacia, o que não deixa de ser um sinal indicador da preocupação ou apreensäo do constituinte (e dos cidadäos, indiretamente) com a possibilidade da sua desobediência, ou da desconsideração de tal supremacia pelos encarregados de lhe dar cumprimento" (Cf. Georgakilas, ob. cit., p. 105). Mas, esta supremacia só se instaurará na medida em que os responsáveis pelo seu cumprimento reconheçam e respeitem tal qualidade, "o que implica, por um lado, na ampla participação política da populaçäo, assim capaz de exercer o controle dos atos normativos de seu interesse e, por outro, numa certa adequaçäo da Constituiçāo formal à realidade material a que se refere" (Georgakilas, ob. cit., p.123).

\section{B. Aplicabilidade do princípio de isonomia}

A lição corrente na doutrina é no sentido de serem todas as normas constitucionais dotadas de eficácia. Algumas, eficácia jurídica e eficácia social; outras, apenas eficácia jurídica. Assim, face ao artigo $5^{\circ}$, inciso I da Constituição Brasileira de 1988, não se pode dizer que há apenas un comando para o legislador ordinário. A aplicabilidade das normas constitucionais referentes aos direitos e garantias individuais é imediata. Há eficácia plena.

A "garantia das garantias", diz José Afonso da Silva, "consiste na eficácia e aplicabilidade imediata das normas constitucionais. Os direitos, liberdades, prerrogativas consubstanciadas no Título II, caracterizados como direitos fundamentais só cumprem sua finalidade se as normas que os expressem tiverem efetividade" (Cf. Curso de Direito Constitucional Positivo, São Paulo, RT, $5^{a}$ ed., 1989, p.402). 
A Constituição preocupou-se com a questão da aplicabilidade imediata de seus dispositivos e, em seu artigo 5", inciso LXXVII, $\S 1^{10}$ determina: "As normas definidoras dos direitos e garantias fundamentais têm aplicação imediata". Incluindose aí todos os direitos fundamentais (individuais, coletivos e sociais, de nacionalidade e políticos).

Outros mecanismos foram previstos para tornar a declaração de aplicabilidade imediata eficiente; o Mandado de Injunção e a Ação de Inconstitucionalidade por Omissão, por exemplo, são instrumentos de tutela constitucional das liberdades (Cf. J. Afonso da Silva, ob. cit., p. 402).

A partir da vigência da Constituição Federal de 1988 todas as normas da legislação ordinária que são conflitantes com a nova ordem constitucional estão derrogadas, portanto, sem eficácia. A continuidade na aplicação sistemática dos dispositivos do Código Civil, em flagrante contradição ao princípio de igualdade formal e material preconizado pela nova Carta Magna, compromete a credibilidade do sistema normativo comandado pela Constituição.

$\mathrm{O}$ artigo $226 \mathrm{da}$ Constituição em vigor aponta com clareza os novos rumos do Direito de Família, resgatando-o do imobilismo dos séculos passados, acertando seus passos com o rítmo do século XXI.

\section{IV - Propostas}

Selecionados e coligidos os dados que viabilizaram o presente estudo sobre a problemática questão da igualdade entre cônjuges, desejamos concluí-lo apresentando algumas propostas com vistas a acelerar a modernização do Direito de Familia Brasileiro. Arrolamos, como prioritárias as seguintes metas:

1 - Reforma integral do Código Civil vigente, principalmente no capítulo referente ao Direito de Familia;

2 Releitura de toda a obra doutrinária e jurisprudencial, escoimando-lhes as reproduções sistemáticas do passado que, já caducas, não servem mais à equânime função do direito e da justiça;

3 - Reconhecimento, por parte dos aplicadores do direito, da eficácia e aplicabilidade das normas constitucionais - afastando as constantes argüiçōes de ineficácia da ORDEM CONSTITUCIONAL que acabariam por retirar a supremacia da CONSTITUIÇÃO;

4 - Conscientizar a população dos seus direitos e deveres, quebrando a passividade que permite a prevalência do perpétuo estado de injustiça na aplicabilidade do princípio de isonomia;

5 Exercício de maior e eficaz controle da constitucionalidade das leis.

À pergunta: quais os meios de que dispomos para concretizar os ítens acima propostos?

Respondemos: A Constituição do Brasil em vigor dispõe de um instrumento denominado "INCONSTTTUCIONALIDADE POR OMISSẪO". 
A Inconstitucionalidade por Omissão ocorre nos casos em que não sejam praticados atos legislativos ou executivos requeridos para tornar plenamente aplicáveis normas constitucionais.

Se, por exemplo, os direitos de familia previstos pela Constituição não se realizarem, por omissão do legislador em produzir as normas necessárias à plena aplicação de tais normas constitucionais, a omissão se caracterizará como inconstitucional.

A ação de "Inconstitucionalidade Por Omissão" tem por escopo obter do legislador a elaboração da lei em questão. A ação direta de inconstitucionalidade por omissão foi elevada, pela atual Constituição, à categoria de garantia constitucional do indivíduo, visto constar do rol previsto no artigo 5 , LXXV.

O artigo 103, § $2^{2}$ da Constituição Federal dispõe: "Declarada a inconstitucionalidade por omissão de medida para tornar efetiva norma constitucional, será dada ciência ao Poder competente para a adoçāo das providências necessárias e, em se tratando de órgäo administrativo, para fazê-lo em trinta dias".

A proposta do item dois não necessita de maiores esforços para ser posta em prática; basta o trabalho da doutrina e da jurisprudência, sem dúvida ambas laboriosas, orientado para uma releitura do Direito de Familia.

A terceira proposta é o desdobramento das primeiras. Se não houver um esforço, no sentido de se reconhecer a legitimidade, a vigência, a eficácia e a supremacia da Constituição de 1988 , as normas constitucionais serão reduzidas a letra morta.

A conscientização da população faz parte da educação e evolução sociopolítica do povo. É função do Estado e de todas as Instituições Educativas, Entidades de Classes e demais segmentos da sociedade, trabalhar para tornar 0 povo brasileiro participante do seu próprio destino. A mulher brasileira, a mãe de familia, não importa o seu nível socio-econômico ou cultural, deve ser esclarecida sobre os seus direitos e deveres.

Quando mantemos, propositalmente, alguém na ignorância, a intenção só pode ser a de podermos, com maior facilidade, dominá-lo, submetê-lo.

A quinta e ultima proposta pode concretizar-se atraves de outra modalidade de Controle de Constitucionalidade: a Inconstitucionalidade Por Ação.

A Inconstitucionalidade Por Ação acontece quando há produção de atos legislativos ou administrativos que contrariem normas ou princípios constitucionais. Pelo princípio de Supremacia da Constituição deve haver compatibilidade vertical entre todas as normas do ordenamento jurídico do país. As normas que não são compatíveis com a Constituição são inválidas (Cf. José Afonso da Silva, ob. cit., p.46). 
V - Bibliografia

AZEVEDO, Álvaro Villaça. Dever de coabitaçâo inadimplemento. São Paulo : Bushatsky, 1976.

. Do concubinato ao casamento de fato. 2.ed. Belém, CEJUP, 1987.

BASTOS, Celso Ribeiro. Comentários à Constituiçāo do Brasil. São Paulo : Saraiva, 1989, v.2.

BERNARDES, Maria Thereza Caiuby Crescenti. Mulheres de ontem? Rio de Janeiro - Século XIX. São Paulo : T.A. Queiroz, 1989.

BEVILAQUA, Clóvis. Direito de família. Ed. Histórica. Rio de Janeiro : Ed. Rio, 1976.

. Comentários ao Código Civil dos Estados Unidos do Brasil. 11.ed., Rio de Janeiro : Francisco Alves, 1965, vols. 1.2.

BITTAR, Carlos Alberto. direito de familia na Constituição de 1988. Revista do Advogado, São Paulo, n.29, p.24-8, ago. 1989.

BOFF, Leonardo. O rosto materno de Deus. Petrópolis : Vozes, 1979. .A Ave Maria - Feminismo e o Espírito Santo. Petrópolis : Vozes, 1980.

BOUZON, E. O Código de Hammurabi. 3.ed., Petrópolis : Vozes, 1980.

BUENO, Ruth. Regime juridico da mulher casada. 3.ed, Rio de Janeiro : Forense, 1972.

CAHALI, Yussef Said. Dos alimentos. São Paulo : Ed. Revista dos Tribunais, 1984. . Divórcio e Separação. 3.ed., São Paulo : Ed. Revista dos Tribunais, 1983.

CASTÁN TOBENAS, José. La condicion social y juridica de la mujer. Madrid : Reus, 1955.

CASTRO, Carlos Roberto de Siqueira. O princípio da isonomia e igualdade da mulher no direito constitucional. Rio de Janeiro : Forense, 1983. 
CUNHA, Roberto Salles. Os novos direitos da mulher. São Paulo : Atlas, 1990.

DEDA, Artur Oscar Oliveira. Direito matrimonial. In: ENCICLOPÉDIA Saraiva do Direito. São Paulo : Saraiva, 1977, v.27. p.272-9.

DINIZ, Maria Helena. Curso de direito civil brasileiro. 5.ed., São Paulo : Saraiva, 1989, v.5.

ESPINOLA, Eduardo. A familia no direito civil brasileiro. Rio de Janeiro : Conquista, 1957.

ESTRELLA, Hernani. Direitos da mulher. Rio de Janeiro : Konfino, 1975.

FARHAT, Alfredo. $A$ mulher perante $o$ direito. São Paulo : Universitária de Direito, 1971.

FERRAZ JR., Tércio Sampaio; DINIZ, Maria Helena; GEORGAKILAS, Ritinha Stevenson. Constituição de 1988 : legitimidade, vigência e eficácia, supremacia. São Paulo : Atlas, 1989.

FERREIRA FILHO, Manoel Gonçalves. Curso de direito constitucional. 17.ed., São Paulo : Saraiva, 1989.

GOMES, Orlando. Direito de familia. 7.ed., Rio de Janeiro : Forense, 1990.

GRECO FILHO, Vicente. Tutela constitucional das liberdades. São Paulo : Saraiva, 1989.

HOLE, Judith; LEVINE, Ellen. Rebirth of feminism. New York : Quadrangle Books, 1971.

MELLO, Celso Antonio Bandeira de. Contédo jurídico do principio de igualdade. São Paulo : Ed. Revista dos Tribunais, 1978.

MIRANDA, Francisco Cavalcanti Pontes de. Comentários a Constituição de 1967, com a emenda n¹/69. Rio de Janeiro : Forense, 1987, T.4. 1974, T.8.

. Tratado de direito privado. 4.ed., São Paulo : Ed. Revista dos Tribunais, . Tratado de direito de família. 3.ed., São Paulo : Max Limonad, 1947, v.2. 
MURARO, Rose Marie. A mulher na construção do mundo futuro. 7.ed., Petrópolis : Vozes, 1972.

PEREIRA, Lafayette Rodrigues. Direitos de familia. 5.ed., São Paulo : Freitas Bastos, 1956.

PIMENTEL, Silvia. Evolução dos direitos da mulher : norma-fato-valor. São Paulo : Ed. Revista dos Tribunais, 1978.

REID, Elizabeth. Los derechos de la mujer en el punto muerto: necessidad de un cambio radical. Revista Intemacional del Trabajo, Ginebra, v.91, n.6, jun. 1975.

RODRIGUES, Silvio. Direito de família. 16.ed., São Paulo: Saraiva, 1989.

ROUSSEAU, Jean Jacques. Discurso sobre a origem $e$ os fundamentos da desigualdade entre os homens. São Paulo : Abril, 1973.

SABINO JUNIOR, Vicente. A emancipaçāo sócio-juridica da mulher. São Paulo : Juriscredi, s.d.

SANTOS, Lucy Rodrigues dos. Bens reservados - proteção ao patrimônio da mulher casada. São Paulo : Saraiva, 1980.

SANTOS, Moacyr Amaral. Primeiras linhas de direito processual civil. 13.ed., São Paulo : Saraiva, 1987, v.1.

SCHMIDLIN, Bruno; CANNATA, Carlo Augusto. Droit privé romain. Géneve : Payot Lausanne CJR, 1984. v.1 : sources, famille, biens.

SILVA, José Afonso da. Curso de direito constitucional positivo. 5.ed. São Paulo : Ed. Revista dos Tribunais, 1989.

SOHM, Rodolfo. Instituciones de derecho privado romano : Historia y sistema. México : Ed. Nacional, 1975.

SOUZA, Hersilio de. Código de Manu. Revista Acadêmica, Recife, v.32, 1924.

SULLEROT, Evelyne. $A$ mulher no trabalho : história e sociologia. Trad. de Antonio Teles. Rio de Janeiro : Ed. Expressão e Cultura, 1970.

TEMER, Michel. Elementos de direito constitucional. São Paulo : Ed. Revista dos Tribunais, 1989. 
VERUCCI, Florisa. A mulher e o direito. São Paulo : Livr. Nobel, 1987.

Mulher. In: ENCICLOPEDIA Saraiva do Direito. São Paulo : Saraiva, 1980. v.53, p.363-78.

São Paulo, janeiro de 1990. 